\title{
Research on the Operation Mode and Theoretical Support of Relationship Lending
}

\author{
Xin Huang \\ Shanghai Zhongzheng Daguang Investment Co. Ltd., Shanghai, China \\ Email: huangxin@zzwealth.cn
}

How to cite this paper: Huang, X. (2017) Research on the Operation Mode and Theoretical Support of Relationship Lending. Social Networking, 6, 53-60. http://dx.doi.org/10.4236/sn.2017.61004

Received: November 14, 2016 Accepted: December 31, 2016 Published: January 3, 2017

Copyright $\odot 2017$ by author and Scientific Research Publishing Inc. This work is licensed under the Creative Commons Attribution International License (CC BY 4.0).

http://creativecommons.org/licenses/by/4.0/

\begin{abstract}
Traditional Folk relations of debit and credit have existed for thousands of years in Chinese society. In the rapidly develop of the context of mobile internet and social network, the borrowing that relies on the relationship among people is not just a financial domain scope discussion topic. In the rapidly developing Chinese mobile Internet, a new anonymous mechanism which is based on interpersonal credit extension and evaluation ultimately form borrowing is continuously formed. In this paper, the author researches and analyzes on what is relationship lending mechanism, the basic operation modes of relationship lending mechanism, a part of theoretical supporting and values.
\end{abstract}

\section{Keywords}

Relationship Lending, Social Network, Credit Evaluation, Theoretical Supports and Research

\section{Introduction}

In the three years from 2013 to 2015, over 2500 establishments work in P2P (Pear to Pear) business in China, groups of heroes seek opportunities in this high-speed expansion market. Fierce competition among companies becomes obvious. The more guest cost is rising in such institutions, risk is accumulating and it is hard to effectively release, although the regulatory border has been formally delimited but it has yet to implement. The nature of the P2P information intermediaries can't be implemented effectively. All types of risk events appear from time to time that platform tender guarantee but it failed to meet its obligations of normal payment [1].

Under this background, more and more internet finance has already contin${ }^{1} \mathrm{P} 2 \mathrm{P}$ lending is financial mode that individual charges an interest by third-party platform to others offer small loans. 
ued to explore and think about how to undertake business innovation in a more effective dimension so that feature with "Decentration" ${ }^{2}$ of the P2P Lending realizes decentration and return to pure information intermediary and MatchMaking platform, track of this business platform only provides trading platform and passage does not operate any risks, all borrowing decisions through the ends of the lending [2].

The author and his project team conduct creative work in social network's risk management and evaluation of relationship among acquaintances as online financial team of China launch innovative concept of Social Finance. They first launch relationship lending based on credit lending facility between familiar people. This article demonstrates and studies on commercial logic effectiveness and theoretical support for this relationship lending between acquaintances.

\section{What Is Mechanisms of Relationship Lending}

Relationship lending is lending method of risk control means by interpersonal credit rating as a starting point, efficient debit and credit relationship quickly as core function, and mechanism of restricted relations as the core. Lending relationship provides the core functions of One-way Anonymous credit and Twoway Anonymous lending at the application layer [3].

Mechanisms of relationship lending in practical work of commercial models is as follows as Figure 1.

1) The relationship is confirmed by scanning phone's address book of Potential Lender ${ }^{3}$ or Willing Lender and Potential Borrower or Willing Borrower. If $\mathrm{PL}$ exists in address book of $\mathrm{PB}$, and $\mathrm{PB}$ also exists in $\mathrm{PL}$, we confirm basic relationship between the two sides, namely, there is an association between PL and PB.

2) Credit $^{4,5}$ (group decision): PL makes credit to $\mathrm{PB}$, credit process is a certain expressional willingness to borrow, that means PL willed to lend the largest amount base on cognition and.

Independent judgment of $\mathrm{PB}$ when $\mathrm{PB}$ needs to borrow makes. The credit through group decision making, in other words, there are many PL1, PL2, PL3, PL4,..., PLn can credit the same PB, and PL1, PL2, PL3, PL4,..., PLn all know

\footnotetext{
${ }^{2}$ Decentration is distributed storage model such as scatter storage and grid are displaced by directed access the mode of centralized storage gradually left off server. In the internet Decentration is also known as Division.

${ }^{3} \mathrm{PL}$ (also called Willing Lender in this paper): Specifically define a person with the Potential tendency of lending money to a borrower.

${ }^{4}$ Credit extension refers to commercial Bank provide bankroll to client in Non-financial institutions, or make guarantee for possible compensation and payment responsibility in the economic activities, such as loan, trade financing, bill financing, finance lease, overdraw and various advance in cash onbalance sheet items, and acceptance of bills, letters of credit opened, letter of guarantee, stand-by letter of credit, confirmation of credit. Guarantee of bond issue, borrowing guarantee, asset sale with recourse and unused irrevocable loan commitment on the off balance sheet activities.

${ }^{5}$ Another definition: credit extension is bank grants loan limit to borrower in a certain term based on the credit standing and economic condition of the borrowers. Within term and amount of credit extension, borrower offers a loan according to their own credit requirements without having to deal with cumbersome procedures of loan approval every time, interest payment can also be reduced as much as possible.
} 


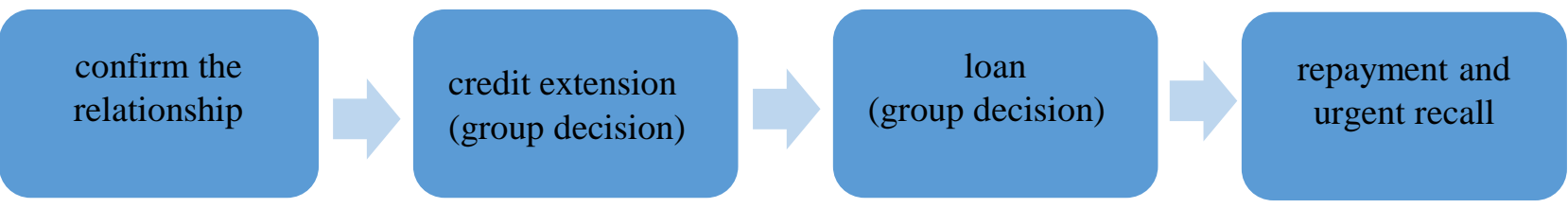

Figure 1. Mechanisms of relationship lending in practical work of commercial models.

credit amount of other PB. No matter whether PL1, PL2, PL3, PL4,.., PLn know each other and confirm the aforementioned relationship they all can be exposed and unobstructed completely understand other PB's willingness to borrow, they make individual decision themselves that reference result from group decision base on cognitive PB.

It should be noted that PL to PB of credit is one-way and anonymous. PB does not know which of the PL1, PL2, PL3, PL4,..., PLn credits it, or the exact amount just follow a path from the PL to PB.

3) Loan (group decision): PB offers all PL to inform them PB is trying to borrow within total credit, appealing PL for lending cash to $\mathrm{PB}$ within the confines of his personal grant by mechanism of relationship lending.

PL can implement two decisions at this time:

First decision: PL agrees to borrow. PL confirms the amount of the loan then completes the borrowing within its credit to PB. Meanwhile, change roles from $\mathrm{PB}$ to Lender, PL transform into Borrower.

Second decision: PL refuses to lend, PL can reject this loan offer without supplying any reason.

Potential causes for rejecting may be lack of funds, not satisfied with the PL drafts borrowing rate and term of borrowing, etc.

No matter which strategy be performed by PL, relational lending mechanism will reveal

The process of loan and the final result of successes or failures only to $\mathrm{PB}$ without disclose to $\mathrm{PB}$ which decision making process for any PL.

The group decision of the process is all the $\mathrm{PB}$ could anonymously understand decision-making behavior and result of other PL1, PL2,..., PLn. this decision gives other decision results of other PL to independently enforce first decision (agree) or second decision (disagree).

4) Repayment: under the relationship lending mechanism, a successful loan due for repayment needn't intervene. B reimburses one or more Lender through the mechanism according to repayment conditions (time, amount of money, interest rate, way) in the offer. B launches this one-way and anonymous repayment. In other words, B doesn't know to repay one or more Lender and sum just intensively repay through this mechanism. Successful loan-repayment record is provided as a reference to adjust credit lines of PL to PB in the future, it could improve the lines.

5) Urging overdue payment: a successful loan becomes overdue that Borrower delays payment. Relational lending mechanism will initiate automatic due loans collection, system will perform the following tips according to overdue time: 
1) 0 - 5 days overdue is natural grace period, the mechanism consider this is well-meaning, non-subjective and tolerable stage. The mechanism reminds borrower everyday that repays as soon as possible and Lender that has started alarm and entered into natural grace period because of the loan is out of date.

2) 6 - 14 days overdue is non-natural grace period, the mechanism consider this behavior of the borrower is well-meaning and non-subjective overdue, mechanism remains optimistic about borrower will be the repayment schedule, further reminders can be taken. under non-natural grace period, mechanism will disclose Lender's name and borrowing balance to Borrower.

At this stage, this unidirectional disclosure to $\mathrm{B}$, the function is generating pressure for B.

3) 15 - 45 days is 1 st class days overdue, the mechanism confirms the borrower overdue that is subjective and non-goodwill. At this stage, mechanism will disclose Borrower's message to all the Lender. Now, two-way anonymous mechanisms of lending officially end. L and B know completely each other. L connects directly with $\mathrm{B}$ to pay on time, the mechanism urges B can independently repay loan.

4) 45 - 90 days is 2 st class days overdue, that means at the urging of Relational lending mechanism, within 30 days, B fails to meet his obligations, his obviously consciousness of malicious default has caused losses to L. The first day, the mechanism will execute global warning, thus prompting $L$ to pay back the money in this stage.

Global warning is a special mechanism in relationship lending, consent was obtained from B, PB, L, PL. After the warning starts, phone's address book of PB is scanned in the stage of confirming the relationship ${ }^{6}$ which will be global and non-selective warned all the people in the address book the content of warning: the loan of B has been clearly overdue, stakeholder be warned credit risk in the address list. The overall and relational characteristic of this mechanism could create huge blows for $\mathrm{B}$.

5) More than 90 days is 3st class days overdue need to start other debt-collection and safeguard mechanism that the loan has been a loss loan from evaluation mechanism of non-performing loan in traditional financial institutions, this paper won't discuss here.

\section{Analysis on the Background of the Establishment of Relationship Lending Mechanism}

The establishment of Chinese social model of interpersonal relationship lending mechanism provides mechanism guarantee for China has pure credit loan among people since a long time ago. Meanwhile provides a different kind of thinking that is loan relationship of Real-name credit + Anonymous lending [4].

1) Relationship lending among acquaintances has a long history in Chinese society

${ }^{6}$ Refer in particular to the contents of confirming the relationship in this chapter. 
Private lending in China dates back to the Spring and Autumn Period and the Warring States Period, early private lending is mostly physical credit. In west Zhou dynasty loaning with interest comes into being, the usury ${ }^{7}$ is emerging. According to Guan $\mathrm{Zi}$, during spring and autumn period, semiannual interest rate of Grain lending even up to $100 \%$ in the Western Qi State. In Qin and Han dynasties, borrowing behavior has been more and more lively with the development of commodity economy. Private lending has integrated in all the fields of everyday life since the Tang and Song, The prevailing of usury cause more and more influence on the economy and people's life. After the establishment of new China, although private lending is repressed, private lending with the nature of life widely exists in folk especially in 1990s, the scale, capital, amount and influence are more and more large [5].

2) Private lending of Chinese relationship shows more and more shortcomings

Private lending of Chinese relationship is constructed that generally is based on acquaintance relation, folk lending is the behavior that acquaintances establish its own loan by agreement personal credit or corresponding guarantees such as house property, commodity.

However, with the increasing demand, the scale of expansion, the folk lending has become increasingly apparent shortcomings.

a) Traditional Chinese credit relation emerges to mainly depend on interpersonal network rather than purely commercial lending, which leads to both Lender and Borrower increasingly concern about the conclusion of contracts for loan, the determination of loan rate, the collection of overdue debt in the notpure loan relationship may affect interpersonal relationships in relational network.

b) According to an uncompleted statistic, Chinese private lending exceeds $\$ 8.6$ trillion $^{8}$. A finite amount of borrowing balance can be provided with the scale and demands are expanding, inefficient lending among acquaintances restrict rapid growth. More and more borrowers lend money from stranger by seeking P2P institutions to increase the risk of loan and difficulty of judging credit risk.

c) Credit behavior works to rely on acquaintance relationship, borrower more pays attention to reveal usage of loan, demand for privacy protection is increasing day by day, therefore borrower refuses to borrow from stranger to avoid privacy exposure.

3) Analysis and research of logic and value base on the five core

The research team analyzes relational lending mechanism which is depended on following the five kind of basic logics and values. These logics and values come from basic attitude of Chinese philosophy and Western classical economics. The team further studies on effectiveness and theoretical support of this mechanism by developing and extending these basic values. 
- Things of a kind come together. People of a mind fall into the same group'.

- Subjective judgment still exists under Hypothesis of Economic Man ${ }^{10}$.

- Nash equilibrium generally exists in the credit relationship among people ${ }^{11}$.

- Credit rating of interpersonal Initiative has sample population in accuracy.

- Credit evaluation has the function of automatic adjustment in the decision group.

\section{Theory Supports for the Research of Relationship Lending Mechanism}

Three core theories of western economics: Nash Equilibrium, Unbiased Estimate and automatic regulation under Rational Expectation, that provide powerful theoretical support for the mechanism of relationship lending and service logic.

1) Nash Equilibrium affects loan decision in the lending relationship

Nash Equilibrium is a strategy combination on which any participant unilaterally changes strategy won't be rewarded. If no player has an incentive to change her strategy while the other players keep their strategies, that is, Nash equilibrium.

And so it is for relationship lending.

While all PL1, PL2, PL3, PL4, ..., PLn provide a credit by independent judgment for $\mathrm{PB}$, individual PL adjusts credit would not affect the whole credit system. The whole credit and Leading still retain dynamic equilibrium state. Once all Potential Lenders change credit to Potential Borrowers, credit value will form balance in new combination.

Simply, in the relationship lending mechanism:

a) Everyone is willing to lend you the money, I am also willing.

b) I don't want to lend you the money, it does not mean that other people don't want.

c) All people are not willing to lend you the money, nor I.

2) Unbiased Estimator verify lines of credit

Unbiased Estimator is that the expectation of parameterized sample estimate equals the real value of parameters. Mathematical expectation of estimator equals the estimated parameter that is called Unbiased Estimator.

Whatever differences may exhibit in the size and amount after group decision making the sample, values of the sample may be considered as actual value of Unbiased Estimator.

The value would be very close to global Credit Value.

Both independent judgment and group decision make new value near to truth-value when new sample joins.

Simply, in the relationship lending mechanism:

If you have 300 friends although there is only 33 people take credit for you, as long as this people are Unbiased chosen, credit still has value close to true value. For example as follows as Table 1.

${ }^{9}$ From "strategies of the warring states" and "Zhou yi".

${ }^{10}$ British economist Adam Smith proposed idea in "The Wealth of the Nations".

${ }^{11}$ Nash Equilibrium is a strategy combination to strategy from each participant optimally react for others. 
Table 1. Form of credit value.

\begin{tabular}{lccc}
\hline & Credit (Yuan) & & Credi (Yuan) \\
\hline PL1 & 30,000 & PL18 & 5000 \\
PL2 & 5000 & PL19 & 5000 \\
PL3 & 5000 & PL20 & 5000 \\
PL4 & 5000 & PL21 & 5000 \\
PL5 & 5000 & PL22 & 5000 \\
PL6 & 5000 & PL23 & 5000 \\
PL7 & 5000 & PL24 & 5000 \\
PL8 & 5000 & PL25 & 5000 \\
PL9 & 5000 & PL26 & 30,000 \\
PL10 & 5000 & PL27 & 5000 \\
PL11 & 5000 & PL28 & 5000 \\
PL12 & 5000 & PL29 & 5000 \\
PL13 & 5000 & PL30 & 5000 \\
PL14 & 30,000 & PL31 & 5000 \\
PL15 & 5000 & PL32 & 5000 \\
PL16 & 5000 & PL33 (PL) & 5000 \\
PL17 & 5000 & & 7272.72 \\
\hline
\end{tabular}

The credit extension for three is 30000 yuan, thirty is 5000 yuan among them.

According to mathematical expectation of E make estimates, 7272 yuan approaches real credit value of Unbiased Estimator.

3) Rational Expectations make that loan fluctuates around credit risk

In Economics and Finance, people generally makes unbiased prediction with forward rate as future spot rate, markets will trade through estimating future spot rate to exchange rate approach true value under mechanism of international arbitrage.

In credit loan, if someone could normally repay within three months is expected all relevant person in three months, then after three months, the man normal repays the loan with a higher probability. Everyone provides capital financing along in normal expectation to make him could achieve goal of repayment by various means.

The possible outcome is the rapidly deteriorating situation of credit that collective demand prepayment, quickly decrease credit extension and non-performing credit.

On the contrary, this causes the borrower difficult to financing by mean of short-term fund, ultimately, struggle to repay.

In short, under rational expectation and conditions of new information is utilized effectively, credit loan has function of automatically adjusts risk, thus to avoids systematic decision-making error. 
For example:

- Most people lose faith in your future ability of paying back loans, and information is effectively delivered to all people.

- Most people provide line of credit rapidly rising or falling, and information is effectively delivered to all people.

The above conditions may soon cause chain reaction under this credit decision. Namely, all lenders judge loan limit rising or falling around PB credit standing of rational expectation, so as to achieve effect of closing account or increasing loan.

In traditional P2P borrowing, less decision errors are caused by information asymmetry, the errors usually appear as everyone no longer believes borrower, almost everyone reduces unwillingness to lend, but some individuals still lend to $\mathrm{B}$ without knowing risk.

\section{Conclusion}

Based on the analysis and thinking of Nash Equilibrium, Unbiased Estimator and automatic regulation under rational expectations, we think credit loan mechanism of strong tie has the stability of credit extension, the relative accuracy of credit-granting Quota, the credit assigning and concurrency management after loan. The current personal credit in China is not yet established. Private lending still has a great space. In this environment, the mechanism is a credit judgment of effective realistic condition and the forming mechanism of loan relation.

\section{References}

[1] Liu, Q.G. (2000) Usurer's Capital in the Ming-Qing Dynasties. Social Sciences Academic Press, 31, 11-15.

[2] Wang, X.-A. (2013)Analysis on the Non-Governmental Credit Loans of SMESTaking Wenzhou as an Example. Journal of Xi'an University of Finance and Economics, 1, 16-20.

[3] Mao, J.H. (2008) A Analysis on China's Private Lending. Chinese Perspective, 11, 56-60.

[4] Xie, H.-M. (2012) The Impact of Network Ties Strength and Enterprises' Learning Capability on the Technological Innovation. Science Research Management, 3, 2024.

[5] John, N. (2009) Game Theory and the Modern Quest for a Code of Nature. Tom Siegfried, 11, 34-37. 
Submit or recommend next manuscript to SCIRP and we will provide best service for you:

Accepting pre-submission inquiries through Email, Facebook, LinkedIn, Twitter, etc. A wide selection of journals (inclusive of 9 subjects, more than 200 journals)

Providing 24-hour high-quality service

User-friendly online submission system

Fair and swift peer-review system

Efficient typesetting and proofreading procedure

Display of the result of downloads and visits, as well as the number of cited articles Maximum dissemination of your research work

Submit your manuscript at: http://papersubmission.scirp.org/

Or contact $\underline{\text { sn@scirp.org }}$ 